\title{
The Impact of Lifestyle-Related Risk Factors on Cardiac Response to Ischemia and Possibilities to Restore Impaired Ischemic Tolerance
}

\author{
T. RAVINGEROVÁ ${ }^{1}$, S. ČARNICKÁ ${ }^{1}$, M. NEMČEKOVÁ ${ }^{1}$, V. LEDVÉNYIOVÁ ${ }^{1}$, \\ A. ADAMEOVÁ ${ }^{2}$, V. K. M. KHANDELWAL ${ }^{3}$, M. ZÁLEŚÁK $^{1}$, F. KOLÁR̆ ${ }^{4}$ \\ ${ }^{1}$ Institute for Heart Research, Slovak Academy of Sciences and Centre of Excellence SAS NOREG, \\ Bratislava, Slovakia, ${ }^{2}$ Department of Pharmacology and Toxicology, Faculty of Pharmacy, \\ Comenius University, Bratislava, Slovakia, ${ }^{3}$ Department of Translational Pharmacology, Consorzio \\ Mario Negri Sud, Santa Maria Imbaro, Italy, ${ }^{4}$ Institute of Physiology, Academy of Sciences of the \\ Czech Republic, Prague, Czech Republic
}

Received March 23, 2012

Accepted May 24, 2012

\section{Summary}

Risk factors (RF) of cardiovascular diseases associated with modern lifestyle, such as stress, chronically increased blood pressure, hyperglycemia and dyslipidemia have a negative impact on the heart exposed to ischemia: their may facilitate its lethal injury (myocardial infarction) and occurrence of sudden death due to ventricular arrhythmias. On the other hand, some stressful stimuli related to RF including reactive oxygen species, transient episodes of ischemia (hypoxia), high glucose and other may play a dual role in the pathogenesis of ischemia/reperfusion (I/R) injury (IRI). Besides their deleterious effects, these factors may trigger adaptive processes in the heart resulting in greater resistance against IRI, which is also a characteristic feature of the female myocardium. However, sensitivity to ischemia is increasing with age in both genders. Current research indicates that comorbidity related to lifestyle may impair the cardiac response to acute ischemia not only by interference with pathophysiological mechanisms of IRI per se, but via suppression of intrinsic protective mechanisms in the heart and its ability to tolerate the ischemic challenges, although the role of RF has not been unequivocally proven. Moreover, even pathologically altered myocardium need not completely lose its adaptive potential. In addition, increased ischemic tolerance can be induced by the pleiotropic (independent of the primary) effects of some hypolipidemic and antidiabetic drugs, even in the diseased myocardium. This review addresses the issue of the impact of RF on cellular cardioprotective mechanisms and the possibilities to restore adaptive potential in subjects challenged with several RF.
Reactivation of adaptive processes in the myocardium taking into consideration gender and age can contribute to optimalization of antiischemic therapy.

\section{Key words}

Lifestyle risk factors - Myocardial ischemia - Gender-related differences $\bullet$ Cardiac adaptation • Pleiotropic effects

\section{Corresponding author}

T. Ravingerová, Institute for Heart Research, Slovak Academy of Sciences, POB 104, Dúbravská cesta 9, 84005 Bratislava, Slovak Republic. Fax: +421 25477 6637. E-mail: usrdravi@savba.sk

\section{Introduction}

Ischemic heart disease (IHD) and its most serious manifestations, such as myocardial infarction and sudden death due to malignant ventricular arrhythmias is a major cause of cardiovascular mortality in modern society. Early restoration of blood supply is essential for the salvage of ischemic myocardium. However, inadequate (delayed) revascularization may lead to ischemia-reperfusion injury (IRI), which is a clinically relevant problem associated with thrombolysis, percutaneous coronary intervention and coronary artery bypass graft surgery (Roberto and Prado 2002, RodrígezSinovas et al. 2007). IRI is manifested by ventricular arrhythmias, reversible contractile dysfunction 
(myocardial stunning) and by the propagation of lethal injury due to the death of cadiomyocytes that were still viable before reperfusion (Matsumura et al. 1998, Hearse 2001). On the cell level, IRI represents a complex cascade of events, where oxidative stress and inflammatory response play the pivotal role (Frangogiannis et al. 2002, Turer and Hill 2010) that besides other factors involves activation of transcription factor NF- $\kappa \mathrm{B}$ as one of the central processes (Li et al. 1999, Hall et al. 2006). The "burst" of reactive oxygen or nitrogen species (ROS or RNS) generation (Ferdinandy et al. 2007) leads to deterioration of cell membrane's integrity, ion transport systems and cation homeostasis (Kaplán et al. 2003, Babušíková et al. 2008), mitochondrial dysfunction (Makazan et al. 2007), activation of apoptotic processes (Halestrap et al. 2007) and subcellular remodeling as a consequence of alterations in cardiac gene expression (Dhalla et al. 2009). Moreover, cardiac function and survival may be dramatically affected by disorders in the metabolism due to perturbations in the dynamic balance between fatty acids (FA) $\beta$-oxidation (FAO) and glucose oxidation as sources of energy in the ischemic heart (Jaswal et al. 2011). Down-regulation of transcription factors PPAR (peroxisome proliferator-activated receptors), nuclear receptors that are considered as key transcriptional regulators of lipid metabolism and energy production (Huss and Kelly 2004) may contribute to deleterious effects of IRI (Yue et al. 2003).

\section{Lifestyle-related risk factors and myocardial response to ischemia}

Myocardial response to ischemia may be markedly impaired by risk factors (RF) of cardiovascular diseases (CVD) associated with modern lifestyle. Human studies clearly indicate that besides chronic stress (Fleming et al. 1987), diabetes and hyperglycemia (Andersson et al. 2010), uncontrolled elevated blood pressure (Perreault et al. 2010) and hyperlipidemia (Deedwania et al. 2009) may lead to a significant aggravation of myocardial IRI. Chronically hypertensive rats (spontaneously hypertensive rats, SHR) or animals exposed to chronic social stress appear to be also more sensitive to ischemia (Chen et al. 2000, Ravingerová et al. 2011a).

The risk of ischemic injury is increasing with age (Babušíková et al. 2008, Turcato et al. 2006) and a common feature of all RF is pro/oxidative dysbalance in the organism and an increased production of ROS or RNS (Haidara et al. 2007, Ferdinandy et al. 2007, Babušíková et al. 2008, Kedziora-Kornatowska et al. 2009). The latter results in endothelial dysfunction, release of vasoactive substances coupled with impaired vascular relaxation and inflammatory response that altogether or separately can exert a negative impact on the heart function under conditions of acute ischemic challenge and subsequently lead to development of heart failure. Figure 1 summarizes the pathways involved in the impact of the above RF on the myocardial sensitivity to ischemia and its major consequences.

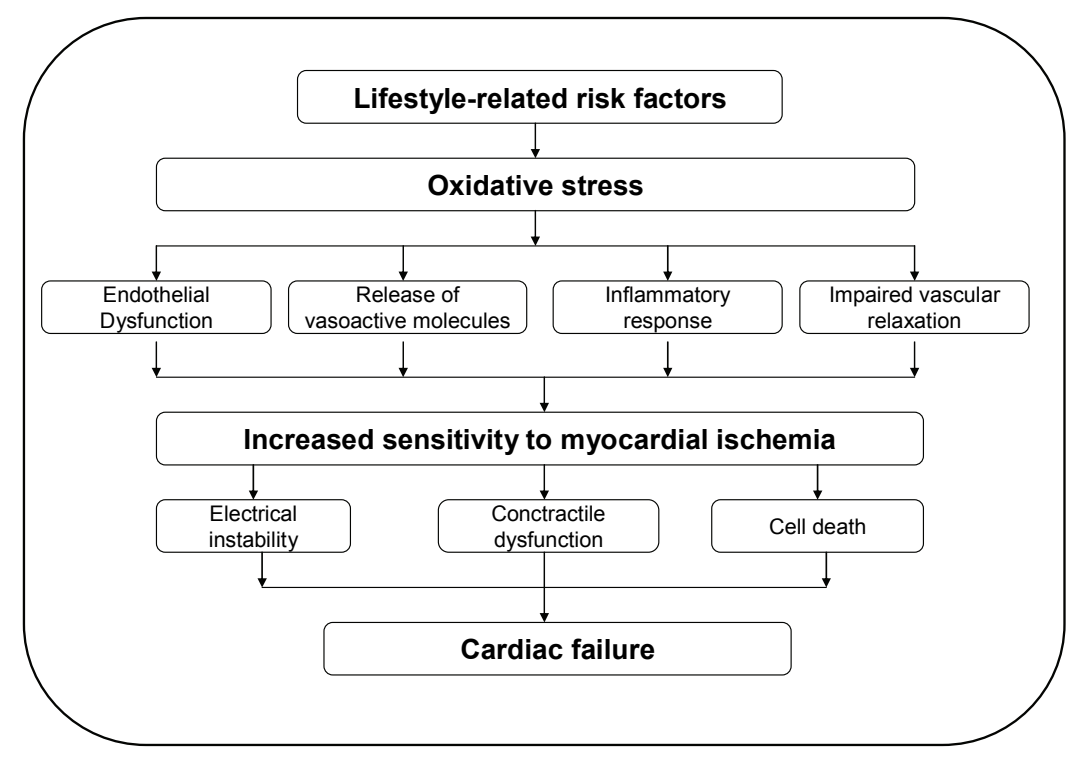

Fig. 1. Lifestyle-related risk factors augment the sensitivity of the myocardium to ischemia. Lifestylerelated risk factors can increase the myocardial sensitivity to ischemia resulting in electrical instability, conctractile dysfunction and cell death leading to the development of heart failure. 
A

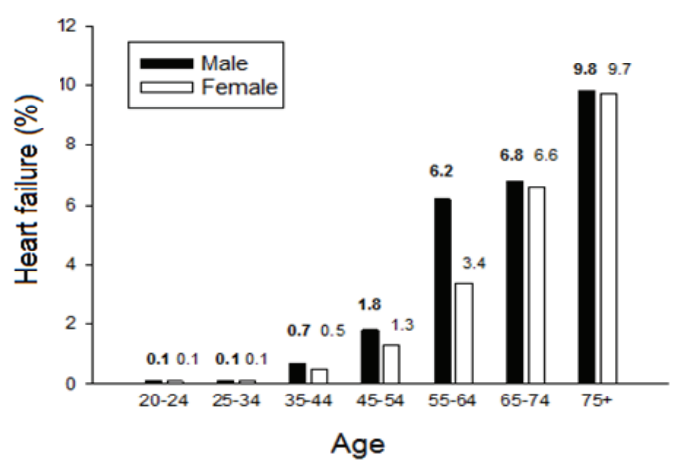

B
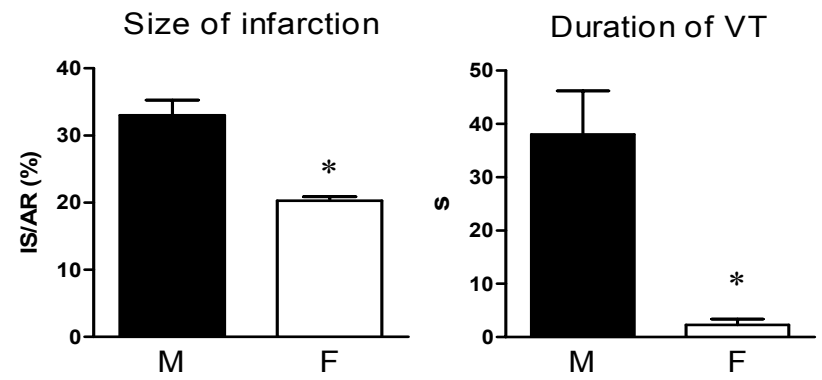

Fig. 2. Effect of gender and age on the ailments related to heart. Outcome of the cardiac morbidities such as heart failure, myocardial infarction and arrhthymias differ with age and gender. (A) The risk of heart failure - dependence on gender and age. (Adapted from SUSSMAN MA: Gender differences in heart failure. In: Cardiac Drug Development Guide. 1st ed. PUGSLEY MK (ed), Humana Press Inc., Totowa, 2003) (B) Effects of gender on the size of infarction and ischemia-induced ventricular arrhythmias in the rat heart. VT - ventricular tachycardia during 30-min LAD occlusion. $\mathrm{M}$ - adult males, $\mathrm{F}-$ adult females. Infarct size (IS) expressed in $\%$ of area at risk (AR) size. $* \mathrm{P}<0.05$ females vs. males

Gender differences also represent a certain risk, since it has been shown as a „handicap“ of being a male in the same age as premenopausal females (Booth and Lucchesi 2008), whereas after menopause, the risk of CVD is increasing in females, partially because of the insufficiency of ovarian hormones that contributes to development of hypertension, diabetes and hyperlipidemia (Duvall 2003). Molecular mechanisms of a distinct response to ischemia in female myocardium remain less investigated. Figure $2 \mathrm{~A}$ shows that the risk of heart failure is 2 -fold higher in males than in females in the age between 55 and 64 , while over 65 , the risk of heart failing becomes equalized. Fig. 2B demonstrates significantly larger size of infarction and longer duration of ventricular tachycardia (VT) in male rats of the same age as adult females (Ledvényiová et al. 2011).

\section{Endogenous cardioprotection}

On the other hand, some stressful stimuli related to RF play a dual role in the pathogenesis of IRI and besides deleterious effects, these factors may trigger adaptive processes in the heart resulting in its greater ischemic tolerance. The concept of heart's own protection is based on the principle that short-term cardiac adaptation to various forms of moderate stress including transient ischemia (ischemic preconditioning, I-PC) (Hearse 2001, Matejíková et al. 2009a), hypoxia (Béguin et al. 2005) or hyperglycemia (Chen et al. 2006, Ravingerová et al. 2010a), as well as pharmacological PC (Matejíková et al. 2009b) increases resistance of the heart against subsequent sustained ischemia. I-PC manifested as a delay/attenuation of processes of necrosis and apoptosis in myocardial cells, improved functional recovery and reduction of life-threatening arrhythmias is a particularly powerful phenomenon observed in all species including humans (Loubani et al. 2004, Vohra and Galinanes 2006). Figure 3 schematically represents triggering endogenous resistance to ischemic injury in the heart.

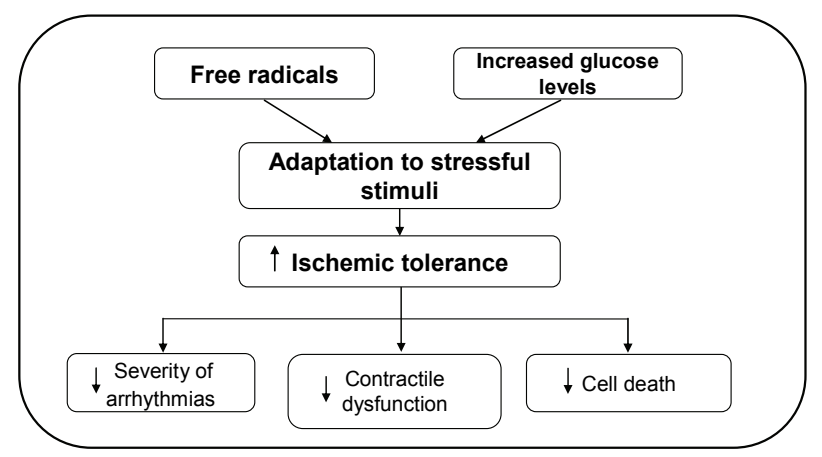

Fig. 3. Beneficial effects of lifestyle-related stressful stimuli. Lifestyle-related risk factors can induce adaptive processes in the heart leading to the cardiac endogenous resistance to ischemic injury, which can result in the reduction of the severity of arrhythmias, contractile dysfunction and cell death.

Besides short-term protective processes, susceptibility to acute ischemia may be reduced by adaptation of the heart to long-lasting stimuli, e.g., chronic hypoxia (Kolár et al. 2007) or some pathological processes, such as hyperglycemia (Chen et al. 2006, Ricci et al. 2008) or experimental diabetes mellitus, in particular, in its early period (Ravingerová et al. 2003, Chen et al. 2006). It is suggested that this form of cardioprotection may share some cell signaling mechanisms with those 
activated during classical I-PC (Ravingerová et al. 2007, 2010a, Balakumar and Sharma 2012). Enzyme systems of protein kinase (PK), such as PKC (Ooie et al. 2003, Hlaváčková et al. 2010) and cascade of phosphatidylinositol-3 kinase (PI3K)/Akt (Ravingerová et al. 2007, 2010a, Ricci et al. 2008), as well as activation of mitochondrial $\mathrm{K}_{\text {ATP }}\left(\mathrm{mK}_{\text {ATP }}\right)$ channels and ROS production play an important role in modulation of IRI in rats adapted to chronic hypoxia and in the diabetic myocardium in the acute phase of the disease (Kolár et al. 2007, Ravingerová et al. 2010a, Balakumar and Sharma 2012). PI3K/Akt is involved in hypertrophic, antiapoptotic, antioxidative processes and in metabolic regulations and acts as an upstream regulator of the enzymes such as PKC, endothelial isoform of NO synthase (eNOS) with subsequently enhanced production of $\mathrm{NO}$ and also activates NF- $\kappa \mathrm{B}$ and glucose transporter (Murphy and Steenbergen 2007). Some of these „survival“" mechanisms have been identified in the acutely diabetic myocardium as well (Ravingerová et al. 2010a, Balakumar and Sharma 2012) coupled with up-regulation of all three isoforms of PPAR not only at baseline conditions, but with preservation of their gene expression after $I / R$, in contrast to down-regulation of PPAR in the non-diabetic hearts (Ravingerová et al. 2010a).

\section{Lifestyle risk factors and myocardial adaptation}

Molecular mechanisms of IRI and endogenous protective processes have been studied in details on experimental models, however, mostly in the intact myocardium of healthy male animals. Thus, the impact of various RF on myocardial IRI still remains not completely elucidated, in particular, in the female myocardium. On the other hand, IHD is a complex disease associated with the influence of numerous lifestyle-related RF, and is age- and gender-dependent. Under these conditions, pathological processes related to basic alterations on the molecular level may potentially interfere with both, the development of ischemic injury itself and with the adaptive mechanisms in the myocardium. As shown in Figure 4, lifestyle-related RF may disrupt the balance between the mechanisms of myocardial sensitivity to ischemia and myocardial ischemic tolerance, which efficiency can be suppressed by various components of comorbidity (Loubani et al. 2004, Ferdinandy et al. 2007). However, the impact of RF on myocardial IRI has not been unequivocally proven.
Moreover, blunting of intrinsic cardioprotective mechanisms has not been considered previously.

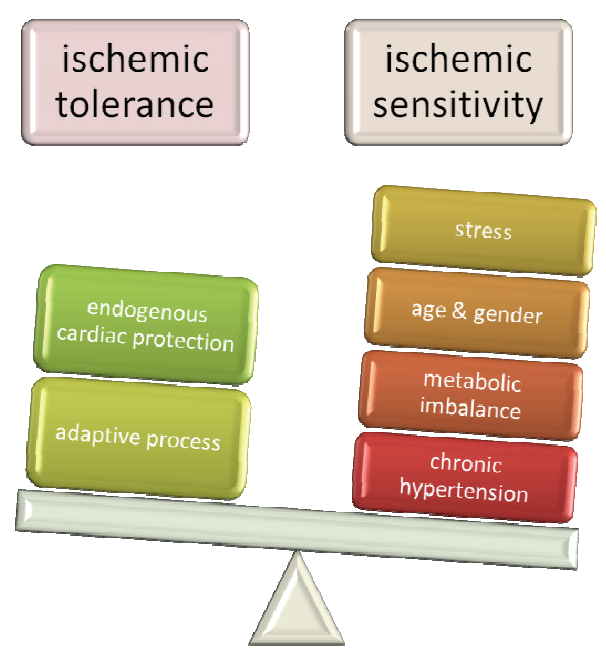

Fig. 4. Interruption of balance between myocardial ischemic tolerance and sensitivity. Modern lifestyle risk factors such as chronic hypertension, metabolic imbalance and stress, in conjunction with age and gender, can disturb the balance between the mechanisms leading to myocardial ischemic tolerance and to myocardial sensitivity to ischemia favouring the processes of cell injury.

Hypercholesterolemia and interference with endogenous cardioprotection

It is not exactly clear why in some animal models of diet-induced hyperlipidemia, the outcome of myocardial IRI is not affected. However, in rabbits fed chow supplemented with $10 \%$ cholesterol (8 weeks), despite elevated expression of anti-apoptotic Bcl-2 protein, lower pro-apoptotic Bax levels and increased Bcl-2/Bax ratio at baseline, myocardial IRI resulted not only in an increased infarct size, but also in an increased extent of cardiomyocyte apoptosis (decreased Bcl-2/Bax ratio and increased activation of caspase-3) in the ischemic myocardium of hypercholesterolemic animals as compared to the controls (Wang et al. 2002). On the other hand, hypercholesterolemia has been suggested to interfere with the intrinsic mechanisms of cardioprotection. However, the mechanisms by which chronic hyperlipidemia abrogates cardioprotective effects of I-PC are not completely understood. The impaired opening of $\mathrm{mK}_{\mathrm{ATP}}$ channels, eNOS uncoupling and excessive generation of superoxide in the hyperlipidemic myocardium could play a role in attenuating I-PCmediated protection against myocardial IRI (Balakumar and Babbar 2012). Moreover, hypercholesterolemia has 
been shown to abrogate the cardioprotective effect of IPC in mice (Kocsis et al. 2010), to attenuate the antiischemic effect of I-PC associated with limitation of ST segment elevation in humans undergoing PCI (Ungi et al. 2005), and to deteriorate enhanced ischemic tolerance in the diabetic heart (Adameová et al. 2007). In this model of 1-week streptozotocin-induced diabetes, concurrent high fat-cholesterol diet-induced hypercholesterolemia abolished all manifestations of greater resistance to ischemia (reduction in the size of infarction, attenuation of myocardial stunning and severity of arrhythmias) including increased fluidization of cardiac mitochondrial membranes implicated in the mechanisms of adaptive responses aimed at the preservation of myocardial energetics under conditions of increased oxygen demand in the diabetic heart (Ferko et al. 2008). Furthermore, decreased myocardial gene expression of PPAR caused by hypercholesterolemia in the diabetic myocardium (Ravingerová et al. 2010a) indicates that promotion of pro-inflammatory and pro-oxidant processes due to reduced levels of PPAR (Smeets et al. 2007) may represent one of the potential mechanisms responsible for the loss of adaptive potential in the diabetic myocardium.

Hypertension, gender and age affect innate cardioprotection

While SHR rats are more prone to ischemic insults (Chen et al. 2000, Ravingerová et al. 2011a), the hearts of female SHR seem to be more resistant to ischemia (Bešík et al. 2007). Our recent data point out not only to the greater tolerance to ischemia in the myocardium of the adult female rats in comparison with their male counterparts (Fig. 2B), but also to the distinct gender-dependent effects of I-PC (Ledvényiová et al. 2011). The failure of I-PC to confer an additional infarct size limitation in the female myocardium, different from its beneficial effect in male hearts, suggests the existence of innate protective phenotype of preconditioning in the hearts of younger adult females. This is in line with the data of Turcato et al. (2006) who reported the interference of aging with the inherent resistance to ischemic injury in the female heart and age-dependency of I-PC in females, but not in males.

Although classical I-PC looses its effectiveness with age independent of the presence of hypertension (Ebrahim et al. 2007), other studies demonstrated the persistence of cardioprotective effect of I-PC in the pathologically remodelled myocardium and in aged normo- and hypertensive animals (Speechly-Dick et al.
1994, Dai et al. 2009). In concert, our study demonstrated that the hypertrophied hearts of SHR rats exhibited not only impaired resistance to ischemia, but showed a certain level of cardioprotection that was inducible by IPC, although its protective effects on some parameters of ischemic injury, such as the size of infarction, were somewhat lower in comparison with the hearts of normotensive animals (Ravingerová et al. 2011a). These results indicate that there are still possibilities to restore the myocardial ischemic tolerance suppressed by RF, in the pathologically altered myocardium by reactivation of the adaptive potential of the organism, although a higher intensity of the preconditioning stimulus (e.g., increasing the number of PC cycles) may be required to reach the threshold of protection (Galagudza et al. 2007).

\section{Possibilities to restore myocardial adaptive potential in the pathologically altered myocardium}

Our previous findings demonstrated that shortterm treatment of rats with hypolipidemic drug simvastatin effectively attenuated all manifestations of IRI and increased the resistance to ischemia in the hearts of diabetic-hypercholesterolemic animals without influencing plasma cholesterol levels indicating pleiotropic (independent of primary) effects of statins (Adameová et al. 2009). Later, we found that these cardioprotective non-lipid effects of simvastatin in normal rats and restoration of ischemic tolerance in diabetic-hypercholesterolemic animals involved upregulation of gene (and protein) expression of PPARalpha (Ravingerová et al. 2009, 2010b). Furthermore, we have also demonstrated that pretreatment of normocholesterolemic rats with a specific PPAR-alpha agonist, a hypolipidemic drug WY-14643, resulted in an elevated gene expression of PPAR-alpha and its target metabolic genes, pyruvate dehydrogenase kinase 4 and carnitine palmitoyltransferase I, regulating glucose metabolism and FAO, respectively, associated with remarkable PI3K/Akt-dependent infarct size-limiting and antiarrhythmic effects (Ravingerová et al. 2012).

Activation of PPAR-alpha and PPAR-gamma isoforms with their synthetic ligands (hypolipidemic drugs fibrates and anti-diabetic drugs glitazones) have been shown to be cardioprotective as manifested by a reduced infarct size and improved postischemic recovery of contractile function in different in vivo and ex vivo models of I/R (Wayman et al. 2002, Yue et al. 2003) in the normal 
and diabetic heart (Bulhak et al. 2009), similar to the effects of I-PC. In these models, PPAR-alpha agonists applied prior to ischemia reversed down-regulation of PPAR and its target genes responsible for the metabolic fuel shifts (decreased FAO and increased glucose oxidation) caused by I/R (Yue et al. 2003). These studies indicate that restoration of FAO may be involved in the mechanisms of protection against acute I/R. In addition, PPAR ligands may modify cell signaling similar to PC, e.g., up-regulate eNOS via activation of PI3K/Akt, in endothelial cells (Wang et al. 2006), and in the normal and diabetic heart (Bulhak et al. 2009). Last but not least, besides metabolic effects, up-regulation of PPAR has been recognized as an important factor regulating inflammation and oxidative stress (Smeets et al. 2007, Ravingerová et al. 2011b). Figure 5 shows main consequences of upregulation of PPAR in the heart exposed to acute $I / R$ that could be relevant to cardioprotection.

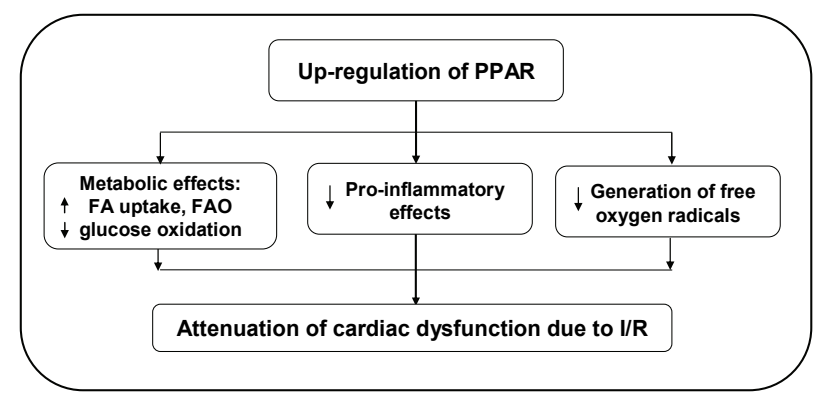

Fig. 5. Proposed beneficial effects of PPAR up-regulation in the ischemic heart. Increased stimulation of PPAR can reverse metabolic shifts in energy sources in the ischemic/reperfused myocardium (from glucose to FA) to maintain an adequate production of energy to restore cardiac function under conditions when coronary flow in no more rate-limiting, to decrease inflammatory response and oxidative stress suggesting its beneficial effects under conditions of acute ischemia/reperfusion. FA - fatty acids, FAO - FA oxidation. (Adapted from Ravingerova et al. 2011b.)

The role of PPAR in the mechanisms of endogenous protection against $\mathrm{I} / \mathrm{R}$ injury is relatively less known, although some further forms of $\mathrm{PC}$, such as "remote" PC (RPC) or "delayed" PC, in particular, their noninvasive modifications (Li et al. 2010, Wu et al. 2011) are being already successfully used in clinical conditions in patients prior to bypass surgery and PCI (Kharbanda et al. 2009). In these forms of cardioprotection, cardiac resistance to ischemia is enhanced by an adaptive stimulus in a distant organ, e.g., by ischemia of renal artery (Lotz et al. 2011a) or limb vessels (Zhou et al. 2010), either immediately after RPC or in its second delayed phase
(Lotz et al. 2011b). It is believed that activation of both, PPAR-alpha and PPAR-gamma isoforms plays an important role in the mechanisms of this form of cardioprotection and that the agonists of PPAR isoforms PPAR-alpha (hypolipidemic drugs fibrates) and PPARgamma (antidiabetic drugs glitazones) themselves may simulate the effect of PC (Lotz et al. 2011a,b). Elucidation of the role of PPAR is important with respect to their modulatory effects on the expression of genes that are responsible for substrate preferences (fatty acids versus carbohydrates) as a source of energy that might be particularly important in the diseased heart under conditions of an acute ischemic insult.

\section{Conclusion}

Lifestyle-related RF may impair the myocardial response to ischemia not only by affecting pathophysiological mechanisms of IRI per se, but also via suppression of the mechanisms of innate cardioprotection. However, since a certain level of resistance to $I / R$ could be observed even in the pathologically altered myocardium, it could be assumed that up-regulation of adaptive mechanisms would restore endogenous cardioprotection. In this respect, we propose that up-regulation of PPAR isoforms by their agonists (hypolipidemic and antidiabetic drugs) may be considered as a potential target in antiischemic therapy of the pathologically altered myocardium by means of reactivation of its own mechanisms of resistance against ischemia. Besides these approaches, based on the previously published studies it could be anticipated that the restoration of the lost adaptive potential in the hearts of subjects challenged with several RF might be possible by means of an increased intensity of the adaptive stimulus, e.g., by employing a higher number of preconditioning cycles, increasing concentration of substances that induce pharmacological PC in the normal myocardium or by means of novel and safer modifications of PC including "remote" or "delayed" PC or by their combination with pharmacological $\mathrm{PC}$ and taking into consideration age- and gender-related differences.

\section{Conflict of Interest}

There is no conflict of interest.

\section{Acknowledgements}

Supported by grants VEGA SR 2/0054/11, 2/0101/12, 1/0638/12, APVV-LPP-0393-09, APVV-0523-10 and APVV-SK-CZ-0199-11. 


\section{References}

ADAMEOVÁ A, KUŽELOVÁ M, ANDELOVÁ E, FABEROVÁ V, PANCZA D, ŠVEC P, ZIEGELHÖFFER A, RAVINGEROVÁ T: Hypercholesterolemia abrogates an increased resistance of diabetic rat hearts to ischemia-reperfusion injury. Mol Cell Biochem 295: 129-136, 2007.

ADAMEOVÁ A, HARČÁROVÁ A, MATEJÍKOVÁ J, PANCZA D, KUŽELOVÁ M, ČARNICKÁ S, ŠVEC P, BARTEKOVÁ M, STYK J, RAVINGEROVÁ T: Simvastatin alleviates myocardial contractile dysfunction and lethal ischemic injury in rat heart independent of cholesterol-lowering effects. Physiol Res 58: 449-454, 2009.

ANDERSSON C, GISLASON GH, WEEKE P, HOFFMANN S, HANSEN PR, TORP-PEDERSEN C, SØGAARD P: Diabetes is associated with impaired myocardial performance in patients without significant coronary artery disease. Cardiovasc Diabetol 9: 3, 2010.

BABUŠÍKOVÁ E, JESENÁK M, DOBROTA D, TRIBULOVÁ N, KAPLÁN P: Age-dependent effect of oxidative stress on cardiac sarcoplasmic reticulum vesicles. Physiol Res 57: S49-S54, 2008.

BALAKUMAR P, SHARMA NK: Healing the diabetic heart: does myocardial preconditioning work? Cell Signal 24: 53-59, 2012.

BALAKUMAR P, BABBAR L: Preconditioning the hyperlipidemic myocardium: fact or fantasy? Cell Signal 24: 589$595,2012$.

BÉGUIN PC, JOYEUX-FAURE M, GODIN-RIBUOT D, LÉVY P, RIBUOT C: Acute intermittent hypoxia improves rat myocardium tolerance to ischemia. $J$ Appl Physiol 99: 1064-1069, 2005.

BEŠÍK J, SZÁRSZOI O, KUNEŠ J, NETUKA I, MALÝ J, KOLÁR F, PIRK J, OSTÁDAL B: Tolerance to acute ischemia in adult male and female spontaneously hypertensive rats. Physiol Res 56: 267-274, 2007.

BOOTH EA, LUCCHESI BR: Estrogen-mediated protection in myocardial ischemia-reperfusion injury. Cardiovasc Toxicol 8: 101-113, 2008.

BULHAK AA, JUNG C, ÖSTENSON CG, LUNDBERG JO, SJÖQUIST PO, PERNOW J: PPAR- $\alpha$ activation protects the type 2 diabetic myocardium against ischemia-reperfusion injury: involvement of the PI3-Kinase/Akt and NO pathway. Am J Physiol 296: H719-H727, 2009.

CHEN H, AZUMA M, MAEDA K, KAJIMOTO N, HIGASHINO H: Impaired heart function and noradrenaline release after ischaemia in stroke-prone spontaneously hypertensive rats. Clin Exp Pharmacol Physiol 27: 664-670, 2000.

CHEN H, SHEN WL, WANG XH, CHEN HZ, GU JZ, FU J, NI JF, GAO PJ, ZHU DL, HIGASHINO H: Paradoxically enhanced heart tolerance to ischaemia in type 1 diabetes and role of increased osmolarity. Clin Exp Pharmacol Physiol 33: 910-916, 2006.

DAI W, SIMKHOVICH BZ, KLONER RA: Ischemic preconditioning maintains cardioprotection in aging normotensive and spontaneously hypertensive rats. Exp Gerontol 44: 344-349, 2009.

DEEDWANIA P, SINGH V, DAVIDSON MH: Low high-density lipoprotein cholesterol and increased cardiovascular disease risk: an analysis of statin clinical trials. Am J Cardiol 104: 3E-9E, 2009.

DHALLA NS, SAINI-CHOHAN HK, RODRIGUEZ-LEYVA D, ELIMBAN V, DENT MR, TAPPIA PS: Subcellular remodelling may induce cardiac dysfunction in congestive heart failure. Cardiovasc Res 81: 429-438, 2009.

DUVALL WL: Cardiovascular disease in women. Mt Sinai J Med 70: 293-305, 2003.

EBRAHIM Z, YELLON DM, BAXTER GF: Ischemic preconditioning is lost in aging hypertensive rat heart: independent effects of aging and longstanding hypertension. Exp Gerontol 42: 807-814, 2007.

FEDINANDY P, SCHULZ R, BAXTER GF: Interaction of cardiovascular risk factors with myocardial ischemia/reperfusion injury, preconditioning, and postconditioning. Pharmacol Rev 59: 418-458, 2007.

FERKO M, HABODÁSZOVÁ D, WACZULÍKOVÁ I, MUJKOŠOVÁ J, KUCHARSKÁ J, ŠIKUROVÁ L, ZIEGELHÖFFER B, STYK J, ZIEGELHÖFFER A: Endogenous protective mechanisms in remodeling of rat heart mitochondrial membranes in the acute phase of streptozotocin-induced diabetes. Physiol Res 57: S67S73, 2008.

FLEMING I, BAUM A, DAVIDSON LM, RECTANUS E, MCARDLE S: Chronic stress as a factor in physiologic reactivity to challenge. Health Psychol 6: 221-237, 1987. 
FRANGOGIANNIS NG, SMITH CW, ENTMAN ML: The inflammatory response in myocardial infarction. Cardiovasc Res 53: 31-47, 2002.

GALAGUDZA MM, NEKRASOVA MK, SYRENSKII AV, NIFONTOV EM: Resistance of the myocardium to ischemia and the efficacy of ischemic preconditioning in experimental diabetes mellitus. Neurosci Behav Physiol 37: 489-493, 2007.

HAIDARA MA, YASSIN HZ, RATEB M, AMMAR H, ZORKANI MA: Role of oxidative stress in development of cardiovascular complications in diabetes mellitus. Curr Vasc Pharmacol 4: 215-227, 2006.

HALESTRAP AP, CLARKE SJ, KHALIULIN I: The role of mitochondria in protection of the heart by preconditioning. Biochim Biophys Acta 1767: 1007-1031, 2007.

HALL G, HASDAY JD, ROGERS TB: Regulating the regulator: NF-kappaB signaling in heart. J Mol Cell Cardiol 41: 580-591, 2006.

HEARSE DJ: Ischaemia, reperfusion and cardioprotection: successes and failures in the journey from molecule to man. Eur Heart J Suppl 3: C11-C21, 2001.

HLAVÁČKOVÁ M, KOŽICHOVÁ K, NECKÁŘ J, KOLÁŘ F, MUSTERS R, NOVÁK F, NOVÁKOVÁ O: Up-regulation and redistribution of protein kinase $\mathrm{C}-\delta$ in chronically hypoxic heart. Mol Cell Biochem 345 : 271-282, 2010.

HUSS JM, KELLY DP: Nuclear receptor signaling and cardiac energetics. Circ Res 95: 568-578, 2004.

JASWAL JS, KEUNG W, WANG W, USSHER JR, LOPASCHUK GD: Targeting fatty acid and carbohydrate oxidation - a novel therapeutic intervention in the ischemic and failing heart. Biochim Biophys Acta 1813: 1333-1350, 2011.

KAPLÁN P, BABUŠÍKOVÁ E, LEHOTSKÝ J, DOBROTA D: Free radical-induced protein modification and inhibition of $\mathrm{Ca}^{2+}$-ATPase of cardiac sarcoplasmic reticulum. Mol Cell Biochem 248: 41-47, 2003.

KEDZIORA-KORNATOWSKA K, SZEWCZYK-GOLEC K, KOZAKIEWICZ M, PAWLUK H, CZUCZEJKO J, KORNATOWSKI T, BARTOSZ G, KEDZIORA J: Melatonin improves oxidative stress parameters measured in the blood of elderly type 2 diabetic patients. J Pineal Res 46: 333-337, 2009.

KHARBANDA RK, NIELSEN TT, REDINGTON AN: Translation of remote ischaemic preconditioning into clinical practice. Lancet 374: 1557-1565, 2009.

KOCSIS GF, CSONT T, VARGA-ORVOS Z, PUSKAS LG, MURLASITS Z, FERDINANDY P: Expression of genes related to oxidative/nitrosative stress in mouse hearts: effect of preconditioning and cholesterol diet. Med Sci Monit 16: BR32-BR39, 2010.

KOLÁŘ F, JEŽKOVÁ J, BALKOVÁ P, BŘEH J, NECKÁŘ J, NOVÁK F, NOVÁKOVÁ O, TOMÁŠOVÁ H, SRBOVÁ M, OŠT'ÁDAL B, WILHELM J, HERGET J: Role of oxidative stress in PKC- $\delta$ upregulation and cardioprotection induced by chronic intermittent hypoxia. Am J Physiol 292: H224-H230, 2007.

LEDVÉNYIOVÁ V, PANCZA D, MATEJÍKOVÁ J, RAVINGEROVÁ T: Enhanced resistance to ischemic injury and differential effects of ischemic preconditioning in isolated female rat hearts. Physiol Res 60: 4, 33P, 2011.

LI C, BROWDER W, KAO RL: Early activation of transcription factor NF-kappaB during ischemia in perfused rat heart. Am J Physiol 276: H543-H552, 1999.

LI SJ, WU YN, KANG Y, YIN YQ, GAO WZ, LIU YX, LOU JS: Noninvasive limb ischemic preconditioning protects against myocardial I/R injury in rats. J Surg Res 164: 162-168, 2010.

LOTZ C, LAZARIOTTO M, REDEL A, SMUL TM, STUMPNER J, BLOMEYER C, TISCHER-ZEITZ T, SCHMIDT J, POCIEJ J, ROEWER N, KEHL F, LANGE M: Activation of peroxisome-proliferator-activated receptors $\alpha$ and $\gamma$ mediates remote ischemic preconditioning against myocardial infarction in vivo. Exp Biol Med (Maywood) 236: 113-122, $2011 \mathrm{a}$.

LOTZ C, LANGE M, REDEL A, STUMPNER J, SCHMIDT J, TISCHER-ZEITZ T, ROEWER N, KEHL F: Peroxisome-proliferator-activated receptor $\gamma$ mediates the second window of anaesthetic-induced preconditioning. Exp Physiol 96: 317-324, 2011 b.

LOUBANI M, FOWLER A, STANDEN NB, GALINANES M: The effect of gliclazide and glibenclamide on preconditioning of the human myocardium. Eur J Pharmacol 515: 142-149, 2005.

MAKAZAN Z, SAINI HK, DHALLA NS: Role of oxidative stress in alterations of mitochondrial function in ischemicreperfused hearts. Am J Physiol 292: H1986-H1994, 2007. 
MATEJÍKOVÁ J, KUCHARSKÁ J, PINTÉROVÁ M, PANCZA D, RAVINGEROVÁ T: Protection against ischemiainduced ventricular arrhythmias and myocardial dysfunction conferred by preconditioning in the rat heart: involvement of mitochondrial K(ATP) channels and reactive oxygen species. Physiol Res 58: 9-19, 2009a.

MATEJÍKOVÁ J, RAVINGEROVÁ T, PANCZA D, ČARNICKÁ S, KOLÁŘ F: Mitochondrial K(ATP) opening confers protection against lethal myocardial injury and ischaemia-induced arrhythmias in the rat heart via PI3K/Akt-dependent and independent mechanisms. Can J Physiol Pharmacol 87: 1055-1062, $2009 \mathrm{~b}$.

MATSUMURA K, JEREMY RW, SCHAPER J, BECKER LC: Progression of myocardial necrosis during reperfusion of ischemic myocardium. Circulation 97: 795-804, 1998.

MURPHY E, STEENBERGEN C: Preconditioning: the mitochondrial connection. Annu Rev Physiol 69: 51-67, 2007.

OOIE T, TAKAHASHI N, NAWATA T, ARIKAWA M, YAMANAKA K, KAJIMOTO M, SHINOHARA T, SHIGEMATSU S, HARA M, YOSHIMATSU H, SAIKAWA T: Ischemia-induced translocation of protein kinase C-epsilon mediates cardioprotection in the streptozotocin-induced diabetic rat. Circ J 67: 955-961, 2003.

PERREAULT S, DRAGOMIR A, ROY L, WHITE M, BLAIS L, LALONDE L, BERARD A: Adherence level of antihypertensive agents in coronary artery disease. Br J Clin Pharmacol 69: 74-84, 2010.

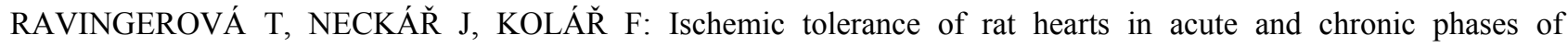
experimental diabetes. Mol Cell Biochem 249: 167-174, 2003.

RAVINGEROVÁ T, MATEJÍKOVÁ J, NECKÁŘ J, ANDELOVÁ E, KOLÁŘ F: Differential role of PI3K/Akt pathway in the infarct size limitation and antiarrhythmic protection in the rat heart. Mol Cell Biochem 297: 111-120, 2007.

RAVINGEROVA T, ADAMEOVA A, KELLY T, ANTONOPOULOU E, PANCZA D, ONDREJČÁKOVÁ M, KHANDELWAL VK, ČARNICKÁ S, LAZOU A: Can J Physiol Pharmacol 87: 1028-1036, 2009.

RAVINGEROVÁ T, ADAMEOVÁ A, MATEJÍKOVÁ J, KELLY T, NEMČEKOVÁ M, KUCHARSKÁ J, PECHÁŇOVÁ O, LAZOU A: Subcellular mechanisms of adaptation in the diabetic myocardium: relevance to ischemic preconditioning in the non-diseased heart. Exp Clin Cardiol 15: 68-76, 2010a.

RAVINGEROVÁ T, ADAMEOVÁ A, ČARNICKÁ S, KELLY T, NEMČEKOVÁ M, LAZOU A: Activation of PPAR-alpha confers protection against myocardial ischemia/reperfusion injury in the rat heart. $J$ Mol Cell Cardiol 48: 160-161, 2010b.

RAVINGEROVÁ T, BERNÁTOVÁ I, MATEJIKOVÁ J, LEDVÉNYIOVÁ V, NEMČEKOVÁ M, PECHÁŇOVÁ O, TRIBULOVÁ N, SLEZÁK J: Impaired cardiac ischaemic tolerance in spontaneously hypertensive rats is attenuated by adaptation to chronic and acute stress. Exp Clin Cardiol 16: e23-e29, 2011 a.

RAVINGEROVA T, ADAMEOVA A, CARNICKA S, NEMCEKOVA M, KELLY T, MATEJIKOVA J, GALATOU E, BARLAKA E, LAZOU A: The role of PPAR in myocardial response to ischemia in normal and diseased heart. Gen Physiol Biophys 30: 329-341, 2011 b.

RAVINGEROVÁ T, ČARNICKÁ S, NEMČEKOVÁ M, LEDVÉNYIOVÁ V, ADAMEOVA A, KELLY T, BARLAKA E, GALATOU E, KHANDELWAL VKM, LAZOU A: PPAR-alpha activation as a preconditioning-like intervention in rats in vivo confers myocardial protection against acute ischaemia/reperfusion injury: involvement of PI3K/Akt. Can J Physiol Pharmacol 90: 1135-1144, 2012.

RICCI C, JONG CJ, SCHAFFER SW: Proapoptotic and antiapoptotic effects of hyperglycemia: role of insulin signaling. Can J Physiol Pharmacol 86: 166-172, 2008.

ROBERTO A, PRADO EA: Ischemia/reperfusion injury. J Surg Res 105: 248-258, 2002.

RODRÍGEZ-SINOVAS A, ABDALLAH Y, PIPER HM, GARCIA-DORADO D: Reperfusion injury as a therapeutic challenge in patients with acute myocardial infarction. Heart Fail Rev 12: 207-216, 2007.

SMEETS PJH, PLANAVILA A, VAN DER VUSSE GJ, VAN BILSEN M: Peroxisome proliferator-activated receptors and inflammation: take it to heart. Acta Physiol 191: 171-188, 2007.

SPEECHLY-DICK ME, BAXTER GF, YELLON DM: Ischaemic preconditioning protects hypertrophied myocardium. Cardiovasc Res 28: 1025-1029, 1994.

TURCATO S, TURNBULL L, WANG GY, HONBO N, SIMPSON PC, KARLINER JS, BAKER AJ: Ischemic preconditioning depends on age and gender. Basic Res Cardiol 101: 235-243, 2006. 
TURER AT, HILL JA: Pathogenesis of myocardial ischemia-reperfusion injury and rationale for therapy. Am J Cardiol 106: 360-368, 2010.

UNGI I, UNGI T, RUZSA Z, NAGY E, ZIMMERMANN Z, CSONT T, FERDINANDY P: Hypercholesterolemia attenuates the anti-ischemic effect of preconditioning during coronary angioplasty. Chest 128: 1623-1628, 2005.

VOHRA HA, GALINANES M: Myocardial preconditioning against ischemia-induced apoptosis and necrosis in man. J Surg Res 134: 138-144. 2006.

WANG TD, CHEN WJ, SU SS, LO SC, LIN WW, LEE YT: Increased cardiomyocyte apoptosis following ischemia and reperfusion in diet-induced hypercholesterolemia: relation to Bcl-2 and Bax proteins and caspase-3 activity. Lipids 37: 385-394, 2002.

WANG Y, YANG Q, YAN JT, ZHAO C, CIANFLONE K, WANG DW: Effects of bezafibrate on the expression of endothelial nitric oxide synthase gene and its mechanisms in cultured bovine endothelial cells. Atherosclerosis 187: 265-273, 2006.

WAYMAN NS, HATTORI Y, MCDONALD MC, MOTA-FILIPE H, CUZZOCREA S, PISANO B, CHATTERJEE PK, THIEMERMANN C: Ligands of the peroxisome proliferator-activated receptors (PPAR- $\gamma$ and PPAR- $\alpha$ ) reduce myocardial infarct size. FASEB J 16: 1027-1040, 2002.

WU YN, YU H, ZHU XH, YUAN HJ, KANG Y, JIAO JJ, GAO WZ, LIU YX, LOU JS: Noninvasive delayed limb ischemic preconditioning attenuates myocardial ischemia-reperfusion injury in rats by a mitochondrial K(ATP) channel-dependent mechanism. Physiol Res 60: 271-279, 2011.

YUE T-L, BAO W, JUCKER BM, GU J-L, ROMANIC AM, BROWN PJ, CUI J, THUDIUM DT, BOYCE R, BURNS-KURTIS CL, MIRABILE RC, ARAVINDHAN K, OHLSTEIN EH: Activation of peroxisome proliferator-activated receptor- $\alpha$ protects the heart from ischemia/reperfusion injury. Circulation 108: 23932399, 2003.

ZHOU W, ZENG D, CHEN R, LIU J, YANG G, LIU P, ZHOU X: Limb ischemic preconditioning reduces heart and lung injury after an open heart operation in infants. Pediatr Cardiol 31: 22-29, 2010. 